JST 8(1)(2019)
JURNALSENI TARI
Terakreditasi SINTA 5
http://journal.unnes.ac.id/sju/index.php/jst

\title{
Strategi Adaptasi Masyarakat Non Hindu pada Pertunjukan Ogoh-Ogoh di Desa Linggoasri Kecamatan Kajen Kabupaten Pekalongan
}

\author{
Gus Miyana Nela Setyaningrum ${ }^{1}$, Agus Cahyono $^{2}$ \\ Jurusan Pendidikan Sendratasik, Fakultas Bahasa dan Seni, Universitas Negeri \\ Semarang, Indonesia
}

\section{Info Artikel}

SejarahArtikel:

Diterima: 12 Juni 2019

Disetujui: 19 Juli 2019

Dipublikasikan: 23 Juli 2019

\section{Keyword:}

adaptation strategies; community of

Non-Hindu; ogoh-ogoh performances

\begin{abstract}
Abstrak
Tujuan penelitian ini ialah untuk memecahkan masalah strategi adaptasi masyarakat non Hindu pada pertunjukan ogoh-ogoh di Desa Linggoasri Kecamatan Kajen Kabupaten Pekalongan. Strategi adaptasi yang menjadi kajian dalam penelitian ini meliputi proses persepsi dan interpretasi, serta sistem kategorisasi. Penelitian ini menggunakan pendekatan fenomenologi dengan metode kualitatif. Teknik pengumpulan data dilakukan menggunakan metode observasi, wawancara, dan dokumentasi. Teknik keabsahan data diperiksa dengan metode triangulasi sumber, teknik, dan waktu. Teknik analisis data melalui tahapan reduksi, penyajian data, dan pengambilan kesimpulan. Berdasarkan analisa data hasil penelitian, persepsi masyarakat non Hindu di Desa Linggoasri dibagi menjadi persepi dari tokoh masyarakat, persepsi dari tokoh agama, persepsi dari tokoh pemerintahan, dan persepsi dari masyarakat umum. Interpretasi masyarakat dikelompokan dalam lima tanggapan yakni hak individu masyarakat, kewajiban sebagai makhluk sosial, kesamaan adat dan tradisi, keinginan menjadikan pertunjukan rakyat. Persepsi dan interpretasi positif dari masyarakat non Hindu di Desa Linggoasri serta dibuktikan pemilihan tindakan selanjutnya yakni dengan munculnya sikap apresiasi dan toleransi serta kebutuhan integratif masyarakat, membuat masyarakat non Hindu dapat beradaptasi pada pertunjukan ogohogoh yang dilaksanakan umat Hindu di Desa Linggoasri.
\end{abstract}




\section{PENDAHULUAN}

Koenjtaraningrat (2015: 144) menjelaskan bahwa menurut ilmu antropologi kebudayaan adalah keseluruhan sistem gagasan, tindakan dan hasil karya manusia dalam kehidupan masyarakat yang dijadikan milik diri manusia dengan belajar. Selanjutnya Sumaryono (2011: 19) menyampaikan ada tujuh unsur kebudayaan yaitu: (1) bahasa, (2) sitem pengetahuan, (3) organisasi sosial, (4) sistem peralatan hidup dan teknologi, (5) sistem mata pencaharian, (6) sistem religi, dan (7) kesenian.

Macam unsur kebudayaan yang seringkali berkaitan yakni kesenian dan sistem religi. Hal tersebut diimplementasikan dengan wujud seni pertunjukan. Seni pertunjukan yang dimaksud adalah seni pertunjukan yang berfungsi sebagai sarana ritual keagamaan.Pertunjukan Ogohogoh yang dilaksanakan sebagai rangkaian kegiatan dalam peringatan Nyepi umat Hindu di Desa Linggoasri Kecamatan Kajen Kabupaten Pekalongan merupakan salah satu pertunjukan yang berkaitan denga ritual keagamaan masyarakat Hindu. Ada beberapa rangkaian peringatan Nyepi umat Hindu, yakni: (1) mekikis atau melasti, (2) tawur kesanga, (3) Nyepi, (4) ngembak geni, dan (5) dharma santi. Pertunjukan ogoh-ogoh masuk dalam rangkaian ke-2 yakni pada saat tawur kesanga.

Hal yang menarik pada penelitian ini adalah bahwa mayoritas masyarakat dimana pertunjukan ogoh-ogoh dilaksanakan merupakan masyarakat non-Hindu. Pertunjukan ogoh-ogoh diadakan di Desa Linggoasri Kecamatan Kajen Kabupaten Pekalongan Provinsi Jawa Tengah. Kabupaten/ Kota Pekalongan yang dikenal sebagai "Kota Santri" dengan mayoritas masyarakatnya beragama Islam dan memiliki beberapa kaum minoritas yang beragam Hindu. Meskipun di Kabupaten/Kota Pekalongan terdapat empat wilayah perkampungan umat Hindu (Kutaraja, Siwalan, Kodya, dan Linggoasri), namun selama ini hanya di Desa Linggoasri yang mengadakan pertunjukan ogoh-ogoh guna melengkapi perayaan Nyepi.

Desa Linggoasri yang sekarang memiliki umat Hindu lebih sedikit daripada masyarakat beragama Islam, dahulunya merupakan masyarakat mayoritas pemeluk agama Hindu. Pada tahun 1966 sebanyak 80\% warga masyarakat Desa Linggoasri memeluk agama Hindu, namun seiring perkembangan waktu dan pengaruh dari luar, pemeluk agama Hindu semakin berkurang. Sehingga pada tahun 2017 presentase penduduk beragama Hindu hanya sekitar $25 \%$. Perubahan ataupun pemindahan dari agama Islam ke agama Hindu tidak menjadikan konflik di masyarakat.

Selain itu, sebagai masyarakat yang memiliki kepercayaan dan cara ibadah yang berbeda, sangat memungkinkan terjadi konflik dalam kehidupan sehari-hari. Namun, perbedaan tersebut tidak menjadi masalah dalam kehidupan bermasyarakat di Desa Linggoasri ini. Oleh karena hal itu, peneliti tertarik dengan bagaimana cara masyarakat yang memiliki perbedaan tersebut dapat beradaptasi dan menjalani kehidupan sosial yang nyaman dan tentram di tengah-tengah perbedaan agama.

Pertunjukan Ogoh-ogoh mulai dilaksanakan di Desa Linggoasri pada tahun 1980-an ketika masyarakat Desa Linggoasri masih mayoritas memeluk agama Hindu. Masyarakat yang dulu banyak memeluk agama Hindu telah berubah menjadi masyarakat Islam, oleh karena itu peneliti tertarik mengapa masyarakat Islam masih menerima keberadaan pertunjukan ogoh-ogoh meskipun mereka sudah tidak lagi memeluk agama Hindu, serta mengapa keberadaan masyarakat minoritas Hindu yang masih diterima di masyarakat mayoritas non Hindu.

Berdasarkan kondisi dua masyarakat yang berbeda kepercayaan ini, peneliti memfokuskan pada kajian strategi adaptasi masyarakat nonHindu pada saat pertunjukan ogoh-ogoh dalam perayaan hari Nyepi. Hal ini dikarenakan pada saat-saat hari besar umat Hindu seperti saat Nyepi banyak sekali masyarakat yang terlibat di dalamnya, masyarakat yang terlibat tak hanya berasal dari umat Hindu itu sendiri tetapi juga melibatkan masyarakat non-Hindu yang ikut berpartisipasi. Oleh karena itu, peneliti meneliti tentang Strategi Adaptasi Masyarakat NonHindu pada Pertunjukan Ogoh-Ogoh di Desa Linggoasri Kecamatan Kajen Kabupaten Pekalongan.

Masalah yang diangkat dalam penelitian ini yaitu bagaimana strategi adaptasi masyarakat non Hindu di Desa Linggoasri pada pertunjukan ogoh-ogoh di Kecamatan Kajen Kabupaten Pekalongan dengan kajian pokok sebagai berikut : 1) persepsi masyarakat non-Hindu di Desa Linggoasri pada pertunjukan ogoh-ogoh; 2) interpretasi masyarakat non-Hindu di Desa Linggoasri pada pertunjukan ogoh-ogoh di Kecamatan Kajen Kabupaten Pekalongan; 3) kategorisasi masyarakat non-Hindu di Desa Linggoasri pada pertunjukan ogoh-ogoh di Kecamatan Kajen Kabupaten Pekalongan.

\section{METODE}

Penelitian ini menggunakan penelitian kualitatif karena pemecahan masalah dilakukan dengan cara menggambarkan, melukiskan serta 
mendeskripsikan keadaan subjek atau objek penelitian pada saat sekarang berdasarkan faktafakta yang ada dan berusaha mengemukakan satu dengan yang lain di dalam aspek-aspek yang diselidiki. Data yang disajikan dalam penelitian ini berupa kata-kata bukan angka. Metode kualitatif digunakan dengan tujuan agar memudahkan dalam menjalin hubungan secara langsung dengan objek penelitian, agar bisa menyesuaikan diri dengan kenyataan di lapangan serta memiliki kepekaan terhadap pengaruh-pengaruh yang timbul di lapangan.

Kajian dalam penelitian ini, yakni strategi adaptasi masyarakat non-Hindu sebagai masalah yang dikaji dilakukan dengan cara mengamati dan menggambarkan keadaan berdasarkan fakta di lapangan. Masalah yang dikaji merupakan suatu kejadian nyata di masyarakat yang dapat dijelaskan setelah mengamati berdasarkan fakta yang ada di tempat kejadian. Data dalam penelitian ini disajikan dalam bentuk deskripstif, dengan mendeskripsikan sajiannya menggunakan kalimat-kalimat yang rinci, lengkap dan mendalam. Data deskriptif dalam penelitian ini menyajikan data yang berupa katakata dan gambar, bukan angka. Data-data tersebut diperoleh dari naskah wawancara, catatan lapangan, foto, dan video.

Penelitian ini merupakan penelitian kualitatif yang mengkaji tentang strategi adaptasi masyarakat non Hindu pada pertunjukan ogohogoh dengan menggunakan pendekatan fenomenologi. Pendekatan fenomelogi digunakan karena masalah yang dikaji pada penelitian ini merupakan permasalahan yang dapat dikaji dengan memahami perilaku maupun tindakan serta interaksi masyarakat guna memecahkan permasalahan strategi adaptasi yang dilakukan masyarakat non-Hindu di Desa Linggoasri.

Orientasi utama penelitian kualitatif dengan menggunakan pendekatan fenomenologi ini adalah untuk memahami perilaku manusia dalam menemukan makna dari pandangan subjek yang dikaji. Prinsip pendekatan fenomenologis yakni selalu berusaha memahami makna dari beragam peristiwa dan interaksi antar manusia dalam suatu situasi. Peneliti fenomenologi memandang tingkah laku manusia, apa yang mereka katakan dan mereka perbuat sebagai hasil dari bagaimana mereka menafsirkan (memahami) dunianya (Bogdan \& Taylor dalam Sumaryanto 2007: 79).

Sasaran atau fokus penelitian adalah kajian adaptasi masyarakat non-Hindu pada saat pertunjukan ogoh-ogoh dalam peringatan hari Nyepi umat Hindu. Subjek peneliti lebih memfokuskan pada masyarakat Desa Linggoasri yakni masyarakat non-Hindu yang ada di Desa Linggoasri, konsumen atau penikmat (penonton) dan juga semua pihak yang bekerjasama dalam pertunjukan ogoh-ogoh di Desa Linggoasri Kecamatan Kajen Kabupaten Pekalongan. Sebagai narasumber dalam penelitian ini yaitu: pemangku adat umat Hindu, ketua PERADA (Persatuan Hindhu Dharma) Kecamatan Kajen, ketuaKarangtaruna Desa Linggoasri, Kepala Desa Linggoasri, beberapa pegawai kelurahan, beberapa masyarakat Islam yang terlibat dalam pertunjukan baik membantu jalannya pertunjukan maupun sebagai penonton, beberapa masyarakat Hindu sebagai pemain pertunjukan. Pemilihan narasumber sematamata untuk mewakili informasi dari kajian yang akan diteliti. Untuk itu dipilih narasumber yang memiliki keluasan dan kedalaman informasi sehingga narasumber adalah informan yang benar-benar memahami dan memiliki informasi yang dibutuhkan peneliti. Peneliti memilih narasumber tersebut karena narasumber diambil dari mereka yang memiliki cukup pengetahuan sebagai informan yang dapat dipercaya. Narasumber yang dipilih juga merupakan bagian dari kedua masyarakat yang berbeda kepercayaan (Hindu dan Islam) sehingga peneliti dapat memperoleh data dari sudut pandang yang beragam.

Pengumpulan data dilakakukan dengan tujuan untuk memperoleh data yang akurat dan valid. Peneltian ini menggunakan teknik pengumpulan data berupa observasi, wawancara, dan dokumentasi. Penelitian ini menggunakan metode observasi terlibat. Peneliti menggunakan metode observasi terlibat karena penelitian yang dilaksanakan memfokuskan pada kajian adaptasi masyarakat pada saat pertunjukan ogoh-ogoh. Selama melakukan observasi peneliti perlu mengumpulkan bahanbahan informasi seni dalam konteks sosialbudaya masyarakatnya. Jadi dengan menggunakan metode observasi terlibat peneliti mampu melihat, mendengar, dan mengetahui lebih dalam masyarakat dan kebudayaan setempat, khususnya dalam mengobservasi adaptasi masyarakat non-Hindu. Observasi dilakukan pada saat pertunjukan Ogoh-ogoh di desa Linggoasri Kecamatan Kajen baik saat persiapan, pelaksanaan dan setelah pertunjukan.

Maryono (2011: 83-85) menjelaskan metode wawancara dalam penelitian kualitatif dapat dilakukan dengan tiga cara, yaitu terstruktur, tidak terstruktur, dan campuran. Pada penelitian ini, peneliti menggunakan metode campuran yakni gabungan antara metode terstruktur dan tidak terstruktur. Disamping membuat jenis-jenis pertanyaan yang telah dirancang sebelum menemui informan, peneliti juga melakukan wawancara yang bersifat terbuka. Peneliti mengembangkan pertanyaan yang tidak tercantum secara 
terstruktur sesuai jawaban dari informan yang semakin terbuka untuk memberikan informasi yang mungkin tidak terfikirkan oleh peneliti namun tetap pada pokok bahasan yang terkait dengan penelitian.

Dokumentasi yang dilakukan oleh peneliti berupa dokumen dari profil Desa Linggoasri. Data-data yang disajikan dalam penelitian ini dapat dibuktikan kebenarannya berdasarkan dokumen yang peneliti dapat ketika melakukan observasi.

Analisis data merupakan proses mengurutkan, menstrukturkan, dan membuat kelompok data yang terkumpul menjadi bermakna. Peneliti menggunakan analisis data menurut Miles dan Huberman. Aktivitas dalam analisis data menurut Miles dan Huberman, yaitu data reduction, data display, dan conclusion drawing/ verification. Pokok masalah yang dikaji adalah strategi adaptasi masyarakat non Hindu pada pertunjukan Ogoh-ogoh, sehingga peneliti memilah dan memilih data-data yang berkaitan dengan pokok kajian yakni persepsi masyarakat, interpretasi masyarakat, dan kategorisasi atau pemilihan sikap masyarakat non Hindu pada pertunjukan Ogoh-ogoh. cara peneliti memilih milih data ialah dengan menyaring dari hasil observasi dan wawancara hal-hal yang berkaitan dengan masalah yang diteliti oleh peneliti. Peneliti menyajikan data dari kajian pokok yang diteliti yakni persepsi, interpretasi dan kategorisasi disajikan secara urut sehingga untuk memecahkan masalah strategi adaptasi masyarakat non Hindu pada pertunjukan ogohogoh dapat ditarik kesimpulan secara tepat dan jelas. Penelitian ini menggunakan analisis induktif, dimana semua simpulan terbentuk dari informasi yang didapat di lapangan. Informasi yang diolah dari lapangan merupakan informasi yang sebenar-benarnya.

\section{HASIL DAN PEMBAHASAN}

\section{Pertunjukan Ogoh-Ogoh}

Wiyoso (2012: 45) menyampaikan bahwa seni adalah produk dari tingkah laku manusia yang dilakukan secara sadar, yang didasari oleh pikir serta olah rasa. Seni pertunjukan adalah aspek-aspek yang divisualisasikan dan diperdengarkan mampu mendasari suatu perwujudan yang disebut sebagai seni pertunjukan. Simatupang (dalam Cahyono 2016: 23) menyampaikan bahwa pertunjukan memiliki tiga unsur pokok yaitu pertunjukan adalah peristiwa yang secara ketat atau longgar bersifat terancang, sebagai sebuah interaksi sosial dengan ditandai kehadiran fisik para pelaku dan peristiwa pertunjukan terarah pada ketrampilan dan kemampuan olah diri jasmanai serta rohani atau kedua-duanya. Pertunjukan selain melibatkan pemain juga melibatkan penonton.

Berbagai aspek seni pertunjukan yang tampak serta terdengar terlibat di dalam tatanan upacara yang berbentuk arak-arakan terdiri dari gerak, suara, dan rupa. Aspek seni pertunjukan terdiri dari: (1) pelaku, (2) gerak, (3) suara, (4) rupa (Kusmayati 2000: 75; Cahyono 2006: 4).

Ogoh-ogoh adalah karya seni patung yang menggambarkan kepribadian butha kala. Dalam ajaran Hindhu Dharma, butha kala mempresentasikan kekuatan alam semesta (Butha) dan waktu (kala) yang tak terukur dan tak terbantahkan. Perwujudan patung ogohogoh yang dimaksud adalah sosok butha kala yang sering digambarkan sebagai sosok yang besar dan menakutkan, biasanya diwujudkan dalam bentuk raksasa. Selain wujud raksasa, ogoh-ogoh biasanya digambarkan dengan makhluk-makhluk atau hewan yakni seperti gajah, naga, kera, babi, dan sebagainya.

Ogoh-ogoh merupakan boneka atau patung yang beraneka rupa yang menjadi simbolisasi unsur negatif, sifat buruk, dan kejahatan yang ada di sekeliling kehidupan manusia. Boneka tersebut dahulu terbuat dari kerangka bambu yang dilapisi kertas. Seiring waktu, kebanyakan ogoh-ogoh saat ini dibuat dengan bahan dasar sterofoam karena menghasilkan bentuk tiga dimensi yang lebih halus. Pembuatan ogoh-ogoh ini dapat berlangsung sejak berminggu-minggu sebelum Nyepi. Waktu pembuatan ogoh-ogoh dapat bervariasi bergantung pada ukuran, jenis bahan, jumlah SDM yang mengerjakan, dan kerumitan desain dari ogoh-ogoh tersebut.

Fungsi utama ogoh-ogoh yakni ogohogoh digunakan sebagai representasi butha kala yang dibuat menjelang hari Nyepi. Setelah ogohogoh dibuat, kemudian diarak beramai-ramai keliling desa pada satu hari sebelum hari Nyepi. Kekuatan tersebut meliputi kekuatan Bhuana Agung (alam raya) dan Bhuana Alit (diri manusia). Dalam pandangan Tattwa (filsafat), kekuatan ini dapat mengantarkan makhluk hidup, khususnya manusia dan seluruh dunia menuju kebahagiaan atau kehancuran. Semua ini tergantung pada niat luhur manusia, sebagai makhluk Tuhan yang paling mulia dalam menjaga dirinya sendiri dan seisi dunia.

Pertunjukan Ogoh-ogoh yang dilaksanakan di Desa Linggoasri tidak semegah yang ada di Bali sebagai daerah pemeluk umat Hindu terbanyak di Indonesia. Pertunjukan ogoh-ogoh dilaksanakan sesuai kondisi alam dan sumber daya manusia yang ada di Desa Linggoasri. Menurut Sedyawati (dalam Cahyono 2006: 28) bahwa dalam setiap masyarakat, kesenian hadir dalam berbagai bentuk dan ungkapan yang spesifik. 
Kespesifikan bentuk dan ungkapan kesenian terjadi karena selain kondisi lingkungan alam, juga karena faktor kondisi dan perkembangan lingkungan sosial budaya tempat kesenian itu muncul.

Bentuk boneka ogoh-ogoh yang dibuat di Desa Linggoasri memiliki tinggi sekitar $2,5 \mathrm{~m}$ dan lebar sekitar 1,5 m. Ogoh-ogoh pada pertunjukan tahun ini terdiri dari 2 boneka. Boneka yang pertama merupakan perwujudan manusia raksasa yang memiliki dua mata besar, mulut lebar dan bergigi taring, berwarna hijau, berkuku panjang, dan berambut panjang tebal. Manusia yang tergambar pada boneka tersebut merupakan sifat manusia yang serakah, mudah marah, dengki, dan jahat. Pada kaki manusia tersebut ditumpangi kepala hewan kera. Kera dipilih karena kera sendiri dipandang memiliki sifat yang licik. Boneka kedua digambarkan menyerupai tubuh manusia yang berkepala babi. Pemilihan hewan babi sebagai bentuk boneka ogoh-ogoh ini dikarenakan sifat babi yang ganas, serakah dan dianggap tidak baik. Tubuh patung kedua tidak jauh berbeda dengan boneka yang pertama, hanya saja ukuran boneka yang kedua ini lebih sedikit kecil.

Ogoh-ogoh dimaknai sebagai simbol wujud keangkaramurkaan. Ogoh-ogoh yang diarak bertujuan sebagai simbol penyerapan segala sifat buruk atau segala sesuatu yang tidak baik masuk ke dalam boneka ogoh-ogoh tersebut, kemudian ogoh-ogoh dimusnahkan dengan harapan bahwa segala sifat buruk yang ada pada diri manusia, segala sesuatu yang tidak baik di alam akan musnah. Meskipun sebenarnya kembali pada diri-sendiri, hanya saja disimbolkan dalam wujud boneka ogoh-ogoh tersebut. Dengan musnahnya semua hal yang tidak baik, maka umat manusia akan kembali damai dan tentram.

Pertunjukan Ogoh-ogoh masuk dalam rangkaian tawur kesanga dalam upacara Nyepi yang diawali dengan ngidung yakni menyanyikan lagu-lagu jawa oleh semua umat di dalam pura. Pada saat kidung masih dilantunkan, kemudian pemangku menghaturkan banten atau sesaji, diiringi doa oleh pemangku dan kidung oleh para umat. Selama prosesi tawur kesanga, didalamnya terdapat upacara yang disebut macaru. Macaru, yakni simbol pembersihan alam semesta yang dilambangkan bambu dengan 4 arah mata angin yang digantungi sesaji di tiap-tiap arahnya. Bagian pusat disebut pancawara, ditiap-tiap arah mata angin digantungi sesaji sesuai warna kepercayaan dalam umat Hindu yakni utara (hitam), timur (putih), selatan (merah), barat (kuning). Setelah prosesi macaru selesai, seluruh umat Hindu melaksanakan sembahyang bersama. Sembahyang merupakan cara umat dalam berdoa dan menyembah Tuhannya. Setelah sembahyang, dilanjutkan dengan pensucian diri dengan cipratan air suci oleh pemangku. Setelah pensucian diri, ogoh-ogoh yang telah diciprati air suci di arak keliling desa.

Urutan prosesi arak-arakan ogoh-ogoh yakni pembawa sapu baris di barisan paling depan untuk menyapu jalan sebagai perlambangan pembersihan alam, lalu diikuti oleh pembawa air suci yang menciprat-cipratkan air suci sepanjang perjalanan guna melambangkan proses pembersihan diri dari segala sifat buruk. Tepat di belakang barisan pembawa air suci diikuti pembawa sesaji, kemudian pembawa obor, dan dibelakang pembawa obor yakni boneka ogoh-ogoh yang pertama. Setelah barisan pembawa boneka ogohogoh, terdapat barisan pembawa alat musik, kemudian di belakang pembawa alat musik terdapat pembawa boneka ogoh-ogoh yang kedua.

Boneka ogoh-ogoh ketika diarak sesekali di orog, yakni gerakan menggoyang-goyangkan patung secara keras, diirngi musik yang semakin riuh, melambangkan sifat kerasnya buta, dan menyeramkan. Pertunjukan diiringi musik berupa kenong, kecrek, gong dan drum. Alat musik dipukul dengan irama yang bergantian. Para pemain alat musik membawa alat musik dibadannya sambil membunyikan alat musik tersebut sepanjang jalan saat arak-arakan pertunjukan. Setelah arak-arakan selesai, boneka ogoh-ogoh lalu dibakar sebagai lambang pemusnahan segala sifat jahat. Dilanjutkan kegiatan dharma wacana yakni petuah dari pemangku adat guna kesiapan Nyepi para umatnya. Setelah penyampaian petuah atau pembekalan guna menghadapi Nyepi, dilanjutkan acara lungsur. Lungsur yakni acara makan bersama atau syukuran sebelum melaksanakan Nyepi esok harinya.

\section{Strategi Adaptasi Masyarakat Non Hindu Pada Pertunjukn Ogoh-Ogoh}

Adaptasi merupakan sebuah sistem harus menyesuaikan diri dengan lingkungan dan menyesuaikan lingkungan itu dengan kebutuhannya (Jazuli 2011: 60). Spradley (dalam Poerwanto 2000: 172) menyatakan bahwa proses adaptasi dipengaruhi oleh persepsi dan interpretasi seseorang terhadap suatu objek yang selanjutnya menuju pada sistem kategorisasi dalam bentuk respon atas kompleksitas suatu lingkungan. Jadi strategi adaptasi merupakan cara seseorang untuk menyesuaikan diri dengan lingkungan atau keadaannya melalui proses persepsi dan interpretasi yang kemudian akan menghasilkan 
suatu kategorisasi yakni sikap yang dipilih dalam mengatasi peristiwa-peristiwa yang akan datang.

Terjadinya persepsi tidak terlepas dari proses penginderaan manusia yang kemudian ditangkap oleh otak manusia setelah itu dicerna menjadi sebuah makna yang akan dikomunikasikan kepada sekitar. Mulyana (2010: 181) juga berpendapat bahwa persepsi yang diungkapkan oleh manusia merupakan bagian dari proses kesadaran dari panca indera manusia, sehingga menghasilkan pesan- pesan bagi diri sendiri dan orang lain. Jadi persepsi merupakan proses masuknya pesan ke dalam otak seseorang yang berasal dari stimulus atau interaksi dengan lingkungan atau individu yang pada akhirnya orang tersebut dapat menyadari atau mempersepsi apa yang diterimanya. Persepsi yang berkembang pada masyarakat memunculkan anggapan-anggapan yang dikelompokan menjadi persepsi dari tokoh masyarakat, tokoh agama, tokoh pemerintahan, dan masyarakat umum. Setiap masyarakat yang memiliki persepsi terhadap pertunjukan ogohogoh memberikan dampak terhadap masyarakat lainnya.

Tokoh masyarakat yakni para pemuda Desa Linggoasri yang terkumpul dalam organisasi Karang Taruna mempersepsikan bahwa pertunjukan ogoh-ogoh merupakan warisan budaya yang berwujud kesenian, yang ditampilkan dalam bentuk seni pertunjukan secara turun temurun yang bersifat keagamaan. Pertunjukan Ogoh-ogoh dianggap mampu memberikan nilai sikap peduli terhadap budaya yang dimiliki di tanah air khusunya di Desa Linggoasri. Selain itu, pertunjukan ogoh-ogoh dianggap sebagai pertunjukan yang menghibur dan tidak mengandung unsur sara sehingga bisa dinikmati semua umur.

Perbedaan agama menyebabkan perbedaan kepercayaan juga keyakinan, serta berbeda ajaran dalam menyembah Tuhan Sang Pencipta. Meskipun dengan keyakinan yang sama bahwa manusia menyembah Tuhan Yang Esa, namun jelas terdapat perbedaan dalam tata cara beribadah antar umat yang berbeda agama. Hal ini sangat dirasakan oleh tokoh-tokoh agama di Desa Linggoasri. Pertunjukan ogohogoh merupakah salah satu wujud perayaan pelengkap ibadah bagi umat Hindu, namun tidak bagi umat Islam. Meskipun perbedaan sangat dirasakan, tetapi tokoh agama Desa Linggoasri menanggapinya secara positif. Tokoh- tokoh agama Islam di Desa Linggoasri mempersepsikan bahwa pertunjukan ogoh-ogoh dijadikan sebagai sarana pelengkap ibadah yang umat Hindu jalankan, dan sebagai pemenuhan emosi akan kebutuhan seni setiap individu.

Pertunjukan ogoh-ogoh yang dijadikan pelengkap yang memiliki makna simbolis dalam perayaan Nyepi umat Hindu yakni sebagai pengusir roh-roh jahat dan hal-hal buruk yang ada pada diri manusia itu sendiri dan lingkungannya, dianggap oleh para tokoh agama Islam Desa Linggoasri merupakan suatu hal baik karena membuang segala hal buruk adalah suatu tindakan yang baik, dan pertunjukan tersebut tidak sampai merugikan umat lainnya yang berbeda kepercayaan, justru adanya pertunjukan mampu menyalurkan perasaan seni tiap-tiap masyarakat yang menyaksikan pertunjukan khusunya masyarakat Desa Linggoasri.

Tokoh pemerintahan di Desa Linggoasri terdiri dari beberapa masyarakat Islam dan masyarakat Hindu. Tokoh pemerintahan non Hindu mempersepsikan bahwa pertunjukan ogoh-ogoh merupakan warisan budaya yang memiliki nilai-nilai sosial. Dengan adanya pertunjukan ogoh-ogoh, masyarakat desa Linggoasri bisa berkumpul bersama dalam rangka persiapan maupun ketika pertunjukan berlangsung. Hal ini menjadikan seluruh masyarakat Desa Linggoasri berbaur menjadi satu sebagai wujud kerukunan antar umat yang berbeda agama. Selain merekatkan ikatan kerukunan antar warga, pertunjukan ogoh-ogoh dianggap sebagai kesenian yang menghibur. Setiap warga tanpa ada batasan jenis kelamin, agama ataupun usia bisa menyaksikan pertunjukan.

Masyrakat non Hindu mempersepsikan bahwa pertunjukan Ogoh-ogoh dijadikan sebagai sarana pemenuhan emosi seni. Dengan adanya pertunjukan Ogoh-ogoh masyarakat non Hindu mampu menyaksikan bahkan terlibat langsung dalam pertunjukan. Keterlibatan inilah yang dijadikan masyarakat sebagai saat-saat menyalurkan emosi estetisnya. Meskipun pertunjukan ogoh-ogoh merupakan pertunjukan yang tergabung dalam tatanan upacara keagamaan, namun tidak terdapat batasan untuk masyarakat lain agama turut bergabung, contohnya dalam berapresiasi.

Masyarakat non Hindu Desa Linggoasri juga mempresepsikan bahwa saat pertunjukan Ogoh-ogoh dilaksanakan, Desa Linggoasri bisa menjadi ramai dalam kehangatan berkumpul bersama menyaksikan pertunjukan. Mengingat Desa Linggoasri merupakan wilayah yang dikelilingi hutan rimbun dan jauh dari perkotaan. Masyarakat di Desa Linggoasri juga beranggapan bahwa ketika pertunjukan Ogohogoh dilaksanakan, banyak wisatawan atau media-media yang meliput jalannya pertunjukan, sehingga mampu meningkatkan daya tarik wisata Desa Linggoasri. Wisata budaya memiliki potensi yang besar untuk dikembangkan, apalagi jika melihat kekayaan seni budaya yang dimiliki bangsa Indonesia sangat beragam, dengan ciri khas dari masing- 
masing daerah. Keunikan budaya masyarakat seringkali menarik minat wisatawan, oleh karena itu keunikan budaya tersebut perlu dijaga agar nilai-nilainya tidak berubah atau menurun mutunya. Keunikan budaya dapat diwujudkan dalam bentuk cindera mata untuk lebih memberi kesan yang khas dan mengingatkan wisatawan pada daerah wisata yang dikunjungi (Hutama dalam Cahyono 2010: 3).

Kegiatan selama proses pertunjukan dianggap memberi dampak positif karena selain menambah kerukunan, berkumpul bersama mempersiapkan pertunjukan juga mampu mengurangi kegiatan-kegiatan negatif terutama para pemuda desa.

Interpretasi adalah seni yang menggambarkan komunikasi secara tidak langsung, namun momunikasi tersebut dapat dengan mudah untuk dipahami. Interpretasi erat kaitannya dengan jangkauan yang harus dicapai oleh subjek dan sekaligus pada saat yang bersamaan diungkapkan kembali sebagai suatu struktur identitas yang terdapat di dalam kehidupan, sejarah, dan objektivitas (Kaelan 1998). Jadi interpretasi adalah kegiatan seseorang memberikan kesan atau pendapat tentang apa yang telah dilihat atau dirasakannya. Seseorang bisa menginterpretasikan sesuatu setelah melalui proses persepsi yaitu ketika seorang individu mendapat stimulus atas apa yang dilihat atau dirasakan melalui alat inderanya dan dipersepsikan di dalam otak, setelah itu individu tersebut bisa memberikan pendapat atau kesan tentang hal tersebut.

Interpretasi merupakan bagian atau wujud dari suatu persepsi yang dimiliki oleh individu. Berdasarkan persepsi-persepsi yang dimiliki oleh masyarakat Desa Linggoasri, peneliti mengelompokkan interpretasi masyarakat non Hindu Desa Linggoasri terhadap adanya pertunjukan Ogoh-ogoh yang dilaksanakan oleh masyarakat yang beragama Hindu antara lain sebagai berikut.

Interpretasi yang pertama yakni, hak individu dalam menganut agama. Masyarakat non Hindu yang ada di Desa Linggoasri yakni mayoritas Islam dan beberapa beragama Budha berpendapat bahwa setiap manusia memiliki hak masing-masing individu. Salah satu hak tersebut ialah hak beragama, yang berarti setiap manusia berhak menganut agama sesuai kepercayaan yang diyakininya. Masyarakat yang tidak beragama Hindu di Desa Linggoasri menghargai kehendak masing-masing individu dalam memilih agamanya, hal ini dibuktikan dengan tidak adanya pertentangan ataupun pemaksaan ketika seseorang warga berganti agama dari agama yang dianutnya secara keturunan menjadi agama baru yang dipercayainya.
Meskipun masyarakat yang memeluk agama Hindu menjadi masyarakat minoritas, namun tidak terdapat kedengkian, sifat iri, ataupun sifat mengucilkan masyarakat minoritas tersebut. Sifat saling menghargai ini ada pada setiap individu masyarakat Desa Linggoasri. Mereka sudah terbiasa hidup berdampingan dengan segala jenis perbedaan termasuk perbedaan agama yang begitu mencolok. Sehingga sifat-sifat menghargai ini tertanam pada diri mereka juga keturunan-keturunan mereka.

Interpretasi kedua yakni meninggalkan kepentingan individu dalam urusan bermasyarakat. Hak-hak individu dalam memeluk agama yang dipercayainya merupakan urusan pribadi setiap individu tersebut, dan dalam urusan bermasyarakat semua warga wajib meninggalkan kepentingan individu pada dirinya masing-masing. Pendapat tersebut menjadikan kehidupan bermasyarakat Desa Linggoasri tentram, akur dan tidak ada perseslisihan meskipun banyak perbedaan. Dalam kegiatan bermasyarakat, status sosial atau kedudukan masyarakat adalah sama, sama sebagai warga masyarakat Desa Linggoasri. Sehingga perbedaan agama yang ada tidak muncul ketika mereka melakukan kegiatan bermasyarakat. Mulai dari kehidupan bertetangga, atau kehidupan di dalam keluarga yang memiliki perbedaan agama pada anggota keluarga, kegiatan mencari nafkah di sawah dan ladang, kegiatan bersama seluruh warga Desa Linggoasri dalam memperingati hari-hari Nasional maupun kegiatan sederhana warga masyarakat seperti gotong royong, semuanya murni mengutamakan kepentingan masyarakat dibanding kepentingan individu.

Interpretasi selanjutnya yakni keyakinan memiliki kesamaan adat tradisi jawa. Sebelum diresmikan bahwa kebiasaan atau adat yang dilakukan warga Desa Linggoasri merupakan kebiasaan yang dilakukan umat Hindu, warga Desa Linggoasri merupakan masyarakat Jawa yang melakukan tradisi jawa. Sehingga walaupun telah memiliki agama yang diyakini, tradisi jawa tetap melekat pada kebiasaan masyarakat di Desa Linggoasri. Tradisi jawa yang masih kental dilakukan yakni seperti mitoni yakni syukuran tujuh bulan untuk seseorang yang sedang mengandung. Ketentuan tradisi tersebut tidak terdapat pada aturan agama, namun merupakan tradisi jawa yang masih dilakukan bersama. Kesamaan tradisi ini menjadikan masyarakat Desa Linggoasri merasa memiliki kesatuan yang sama dan utuh sebagai warga masyarakat yang tinggal di wilayah yang sama meski memiliki perbedaan agama.

Interpretasi yang terakhir yakni keinginan menjadikan pertunjukan Ogoh-ogoh sebagai 
pertunjukan rakyat Masyarakat Desa Linggoasri berpendapat bahwa masyarakat non Hindu sangat menghargai adanya keberagaman kesenian yang ada di Desa Linggoasri. Mereka menginginkan kesenian yang dimiliki Desa Linggoasri akan tetap lestari. Sama halnya pada pertunjukan ogoh-ogoh yang dilaksanakan di Desa Linggoasri, pertunjukan Ogoh-ogoh yang dilakukan dalam rangkaian upacara Nyepi umat Hindu diharapkan tidak hanya menjadi pertunjukan yang dilaksanakan atas dasar prosesi ritual keagamaan. Meskipun yang terikat dengan prosesi ritual merupakan masyarakat Hindu, namun masyarakat non Hindu akan dapat lebih berpartisipasi tidak hanya sekedar berapresiasi. Ketika pertunjukan dijadikan tradisi bersama, kemungkinan akan lebih menarik dan lebih ramai dari tahun ke tahunnya, meskipun tidak melupakan fungsi pertunjukan tersebut sebagai rangkaian upacara keagamaan.

Selain keinginan pertunjukan ogoh-ogoh menjadi pertunjukan rakyat, masyarakat Desa Linggoasri juga berkeinginan bahwa pertunjukan ogoh-ogoh bisa dijadikan identitas budaya Desa Linggoasri, mengingat bahwa belum ada suatu karya seni atau budaya khusus yang menjadi identitas desa. Verulitasari (2016: 2) menyampaikan bahwa identitas budaya adalah rincian karakteristik atau ciri-ciri sebuah kebudayaan yang dimiliki oleh sekelompok orang yang kita ketahui batas-batasnya tatkala dibandingkan dengan karakteristik atau ciri-ciri kebudayaan orang lain.

Spradley (dalam Poerwanto 2000: 172) menyebutkan sistem kategorisasi memungkinkan seseorang untuk mengidentifikasikan aspek-aspek lingkungan yang sesuai untuk diadaptasi, memberikan arah bagi perilaku mereka sehingga memungkinkannya dapat mengantisipasi peristiwa-peristiwa yang akan datang. Sistem kategorisasi terjadi setelah seseorang melalui tahapan persepsi dan interpretasi. Sehingga dalam kategorisasi, seseorang bisa menentukan sikap yang dia pilih dalam menghadapi suatu peristiwa. Wujud dari sistem kategorisasi masyarakat non Hindu Desa Linggoasri terdiri dari sikap apresiasi, toleransi, dan pemenuhan kebutuhan integratif.

Apresiasi merupakan kegiatan atau aktivitas menikmati dan merasakan nilai-nilai pada suatu karya seni dan memberinya penghargaan atas kesan estetis yang ditampilkan. Sesuai dengan salah satu fungsi kesenian yakni sebagai sarana hiburan, masyarakat non Hindu sangat mengapresiasi pertunjukan ogoh-ogoh yang dilakukan umat Hindu dalam merayakan Nyepi. Seluruh masyarakat non Hindu menjadi penonton yang melihat pertunjukan dari awal hingga akhir. Hal ini juga berkaitan dengan kebutuhan manusia akan berkesenian.

Masyarakat non Hindu yang tidak bergabung dalam pertunjukan Ogoh-ogoh berdiri di sepanjang rute arak-arakan pertunjukan untuk melihat jalannya pertunjukan. Tak hanya berdiri melihat, beberapa penonton ikut masuk dalam barisan arak-arakan dan mengikuti jalannya pertunjukan. Karena pertunjukan Ogoh-ogoh di mulai ba'da shalat Isya untuk umat Islam, beberapa penonton masih mengenakan alat sholat seperti mukena dan sarung. Tidak ada larangan ataupun deskriminasi pada pertunjukan. Justru penonton yang ikut bersorak dan penonton yang turut masuk dalam barisan arak-arakan semakin membuat pertunjukan ramai. Disitu dapat terlihat keberagaman yang tetap menjadi satu kesatuan.

Tidak sekedar menonton, mereka tentu mengabadikan pertunjukan dengan mengambil dokumentasi foto atau video. Hal ini membuktikan bahwa mereka menyukai dan bangga terhadap pertunjukan yang dilaksanakan umat Hindu meskipun mereka bukanlah umat Hindu. Apresiasi pertunjukan tidak hanya berasal dari masyarakat yang sengaja menonton, namun juga aparat keamanan yang bertugas mengawasi dan menertibkan lalu lintas karena prosesi apertunjukan terletak di jalan raya.

Sikap yang dipilih masyarakat non Hindu selanjutnya yakni toleransi. Toleransi merupakan sikap saling menghargai dan menghormati antar individu atau antar kelompok dalam kehidupan masyarakat. Sikap toleransi menghindari adanya diskriminasi meskipun banyak terdapat kelompok atau golongan yang berbeda dalam suatu kehidupan bermasyarakat. Seperti keadaan masyarakat Desa Linggoasri yang banyak memiliki perbedaan, terutama dalam kepercayaan agama yang dianut, tidak menjadikan masyarakat mendeskriminisasi kelompok tertentu. Seluruh warga masyarakat memiliki sikap toleransi dalam berbagai hal. Beberapa sikap toleransi yang dilakukan warga masyarakat sebagai strategi penyesuaian diri terhadap perbedaan yang ada yakni sebagai berikut dibuktikan dengan seluruh warga membatu dalam persiapan pertunjukan, tidak membunyikan pengeras suara ketika perayaan Nyepi dilaksanakan, tidak adanya pertentangan pendapat dalam musyawarah, tidak adanya perbedaan pelayanan masyarakat oleh pemerintah, adanya pertemuan rutin setiap menjelang diadakannya kegiatan-kegiatan keagaman baik kegiatan agama Hindu maupun non Hindu 
Seluruh warga Desa Linggoasri membantu persiapan pertunjukan ogoh-ogoh. Dimulai dari adanya musyawarah bersama warga baik Hindu maupun non Hindu bahwa akan dilaksanakan pertunjukan ogoh-ogoh, sumbangan dana dari warga, proses pembuatan boneka ogoh-ogoh, hingga saat pentas seluruh warga berperan membantu jalannya pertunjukan. Meskipun ide dasar pertunjukan ogoh-ogoh ditentukan oleh anggota PERADA (Persatuan Hindhu Dharma) Desa Linggoasri, namun secara keseluruhan merupakan musyawarah bersama warga Desa Linggoasri. Kemudian sumbangan dan dari warga secara sukarela juga turut membantu dalam keperluan perlengkapan pertunjukan. Pada saat proses pembuatanpun, tak hanya para pemuda Hindu yang membantu persiapan, pemuda non Hindu juga turut berkumpul di pura untuk membantu membuat boneka ogoh-ogoh.

Semua masyarakat ikut andil dalam pertunjukan ogoh-ogoh. Seluruh umat Hindu si empunya pertunjukan yang terdiri dari pemangku adat, pembawa air suci, pembawa sapu, pembawa sesaji, pembawa obor, pembawa patung ogoh-ogoh, pemusik, semuanya adalah masyarakat Hindu. Namun terdapat juga aparat keamanan yang mengamankan lalu lintas, dan masyarakat non Hindu yang juga ikut tergabung sebagai penonton pertunjukan maupun yang mengikuti kegiatan arak-arakan ogoh-ogoh.

Keesokan hari setelah pertunjukan ogohogoh dilaksanakan, seluruh umat Hindu melaksanakan Nyepi yang berarti mereka tidak melakukan aktivitas seperti biasanya. Sebagai acara penyambutan tahun baru Saka, masyarakat Hindu menjalankan Nyepi dengan melaksanakan Catur Brata Nyepi sebagai simbol perenungan atau instropeksi diri guna membersihan diri dari segala sifat buruk manusia yang mungkin selama satu tahun lalu mereka perbuat. Dalam hal ini umat Hindu melakukan 4 hal yang disebut Catur Brata, yakni amati geni, amati lelungan, amati karya, dan amati lelanguan. Amati geni atau tidak boleh menyalakan api. Api dan lampu tidak boleh dinyalakan pada saat Nyepi. Sebenarnya api disini lebih diutamakan kepada api yang ada di dalam diri seseorang seperti kemarahan, iri hati, dan pikiran yang tidak baik. Amati karya atau tidak bolek bekerja. Amati lelungan atau tidak boleh berpergian. Amati lelanguan atau tidak boleh bersenang-senang.

Sebagai wujud menghargai dan mendukung kegiatan umat Hindu dalam melaksanakan ibadahnya, setiap hari Nyepi, warga Islam tidak menggunakan pengeras suara ketika mengumandangkan Adzan. Selain itu, masyarakat non Hindu juga tidak membuat kegiatan atau acara yang ramai atau riuh pada hari Nyepi tersebut. Pun sebaliknya, ketika warga Islam menjalankan puasa Ramadhan, masyarakat Hindu tidak pernah mengumbar bebas makan di luar rumah, bahkan ketika satu lingkungan keluarga ada anggota keluarga yang sedang berpuasa, anggota lainpun akan ikut tidak makan hingga waktunya berbuka.

Dalam hal musyawarah suatu kegiatan desa, seluruh warga bisa dengan bebas mengutarakan pendapatnya dan kesepakatanpun akan diperoleh melalui musyawarah bersama. Tidak ada perbedaan oleh siapa, menganut agama apa, memiliki status sosial apa pendapat itu di kemukakan. Sesuai dengan prinsip warga masyarakat, bahwa mereka akan meninggalkan kepentingan individu ketika harus berurusan dengan kehidupan sosial bermasyarakat.

Seluruh warga masyarakat Desa Linggoasri apapun agamanya memiliki kedudukan yang sama dalam hal pelayanan pemerintah baik pemerintah desa maupun kota. Keberagaman dalam hal pemerintah juga terdapat di Desa Linggoasri, dibuktikan dengan agama para perangkat desanya, yakni ada yang beragama Islam, Hindu, dan Budha.

Selain proses musyawarah yang murni dari kesepakatan bersama, pelayanan oleh pemerintah juga setara untuk semua warganya. Tidak ada diskrimasi atas dasar agama yang berbeda. Seperti misalnya proses pembuatan akta kelahiran, kartu keluarga, urusana surat nikah, semuanya akan diurus secara adil tanpa melihat agama yang dianut warga pemohon pelayanan tersebut.

Sebagai wujud menghargai perbedaan dan rasa bangga terhadap adanya perbedaan, setiap malam menjelang Hari Kemerdekaan Republik Indonesia, seluruh masyarakat Desa Linggoasri berkumpul dalam satu tempat untuk melaksanakan doa dan syukuran bersama. Doa dipanjatkan sesuai keyakinan agamanya masingmasing untuk memperoleh hidayah dari Tuhan Yang Kuasa dan alam yang telah memberi nikmat. Setelah memanjatkan doa bersamasama, seluruh warga melakukan syukuran dengan menyantap hidangan tumpeng dan hasil bumi dari Desa Linggoasri yang telah disiapkan secara bersama-sama.

Wujud sistem kategorisasi yang ketiga yaitu pemenuhan kebutuhan integratif. Kebutuhan manusia untuk mengungkapkan perasaan keindahan tampaknya berlaku secara universal dan berlangsung sejak lama. Hasilhasil penelitian lintas budaya dan pra-sejarah pada aneka ragam kebudayaan telah menunjukan bukti-bukti bahwa tidak ada kebudayaan, yang pernah kita kenal, yang di dalamnya tidak menampung bentuk-bentuk dari ekspresi estetik. Ini menunjukkan bahwa betapa pun sederhananya kehidupan manusia, di sela- 
sela memenuhi kebutuhan primernya, mereka senantiasa mencari peluang untuk memenuhi hasratnya dalam mengungkapkan dan memanfaatkan keindahan (Rohidi 2000: 17).

Masyarakat Desa Linggoasri yang mayoritas merupakan petani dan buruh tidak hanya mementingkan kecukupan kebutuhan primer dan sekundernya, hal ini dibuktikan dengan tindakan seluruh masyarakat dalam mengekspresikan cita rasa dalam menikmati keindahan melalui suatu pertunjukan kesenian. Meskipun kesenian yang dihadirkan berkaitan dengan suatu agama tertentu yang dianut masyarakat, mereka (para penonton atau penikmat) tidak memandang kesenian itu diadakan oleh siapa dan dari agama apa. Namun, para penikmat yakni warga masyarakat dengan sangat antusias menyaksikan jalannya pertunjukan, bahkan sampai mengikuti jalannya arak-arakan ogoh-ogoh. Pemberian tepuk tangan, pengabadian melalui dokumentasi pribadi merupakan bukti bahwa masyarakat Desa Linggoasri apapun golongannya melakukan kegitan pengekpresian terhadap keindahan.

\section{SIMPULAN}

Pertunjukan Ogoh-ogoh merupakan pertunjukan yang menggunakan boneka buta atau raksasa sebagai simbol keangkaramurkaan atau sifat-sifat buruk manusia. Pertunjukan ogoh-ogoh di Desa Linggoasri dilaksanakan pada malam hari sebelum melaksanakan upacara Nyepi. Keberadaan pertunjukan tersebut tidak menjadikan masyarakat yang beragama non Hindu merasa terbebani. Strategi adapatasi yang dilakukan masyarakat non Hindu melalui tiga tahapan, yakni persepsi, interpretasi dan kategorisasi. Persepsi masyarakat non Hindu di Desa Linggoasri dibagi menjadi persepi dari tokoh masyarakat, persepsi dari tokoh agama, persepsi dari tokoh pemerintahan, dan persepsi dari masyarakat umum. Persepsi masyarakat non Hindu di Desa Linggoasri dipengaruhi oleh faktor internal dan faktor eksternal. Faktor internal yakni kemampuan atau ketajaman alat indera dan perhatian yang terkonsentrasi.

Interpretasi atau tanggapan masyarakat non Hindu di desa Linggoasri terhadap pertunjukan ogoh-ogoh yakni: 1) masyarakat memilik hak individu yakni hak menganut agama yang dipercayainya, 2) sebagai makhluk sosial, masyarakat wajib meninggalkan kepentingan individu ketika menjalankan urusan bermasyarakat, 3) semua warga Desa Linggoasri memiliki keyakinan bahwa mereka mempunyai kesamaan adat dan tradisi yakni tradisi Jawa, 4) masyarakat non Hindu Desa Linggoasri menginginkan menjadikan pertunjukan Ogohogoh tidak hanya sebagai pertunjukan atas dara keagamaan, namun bisa dijadikan pertunjukan rakyat meskipun tidak melepaskan unsur keagamaan yang memang wajib ada.

Kategorisasi atau sikap yang dipilih warga masyarakat non Hindu di Desa Linggoasri yakni: 1) apresiasi, 2) toleransi, hal ini dibuktikan dengan seluruh warga membatu dalam persiapan pertunjukan, tidak membunyikan pengeras suara ketika perayaan Nyepi dilaksanakan, tidak adanya pertentangan pendapat dalam musyawarah, tidak adanya perbedaan pelayanan masyarakat oleh pemerintah, adanya pertemuan rutin setiap menjelang diadakannya kegiatan-kegiatan keagaman baik kegiatan agama Hindu maupun non Hindu, 3) pertunjukan Ogoh-ogoh dijadikan kegiatan pemenuhan kebutuhan integratif setiap individu di Desa Linggoasri. Jadi bisa disimpulkan bahwa masyarakat non Hindu Desa Linggoasri sudah mampu beradaptasi dengan adanya pertunjukan Ogoh-ogoh yang dilaksanakan umat Hindu. Sikap toleransi yang tinggi semakin membuat Desa Linggoasri menjadi desa yang benar-benar membuktikan semboyan Bhineka Tunggal Ika, yakni berbedabeda tetapi tetap satu jua. Sikap masyarakat Desa Linggoasri yang saling menghargai dan juga saling mendukung, maka pertunjukan Ogoh-ogoh akan mampu berkembang lebih baik.

Pertunjukan Ogoh-ogoh masih terlihat sederhana, oleh karena itu kreasi dan dukungan seluruh masyarakat Desa Linggoasri perlu ditingkatkan agar pertunjukan semakin berkembang baik. Kepedulian dan sikap masyarakat terutama masyarakat Desa Linggoasri sangat perlu dipertahankan guna menanggulangi kejadian-kejadian yang akan datang. Ketentraman dan kenyamanan kehidupan bermasyarakat Desa Linggoasri sangat perlu dipertahankan dan bisa dijadikan panutan kehidupan sosial yang baik bagi masyarakat lain di seluruh ibu pertiwi.

\section{DAFTAR PUSTAKA}

Asrori, Mohammad. 2009. Psikologi Pembelajaran. Bandung: CV Wacana Prima.

Andriani, Susi, dan Oksiana Jatiningsih. 2015. "Strategi Adaptasi Sosial Siswa Papua Di Kota Lamongan". Kajian Moral dan Kewarganegaraan. Vol 02. Nomor 03. Hlm. 530-544. Surabaya. Universitas Negeri Surabaya.

Cahyono, Agus. 2006. "Pola Pewarisan NilaiNilai Kesenian Tayub". Harmonia Jurnal 
Pengetahuan dan Pemikiran Seni. Vol.VII. Nomor 1. Hlm. 23-36. Semarang. Jurusan Pendidikan Sendratasik. Fakultas Bahasa dan Seni. Universitas Negeri Semarang.

Cahyono. Agus. 2006. "Seni Pertunjukan Arakarakan Dalam Upacara Tradisional Dugdheran di Kota Semarang". Harmonia Jurnal Pengetahuan dan Pemikiran Seni. Vol. VII. Nomor 3. Hlm. 67-77. Semarang: Universitas Negeri Semarang.

Cahyono, A, Bintang Hanggoro P. 2010. "Pemanfaatan Tari Barongsai untuk Pariwisata". Harmonia Jurnal Pengetahuan dan Pemikiran Seni. Vol.X. Nomor 10. H1m. 1-12. Semarang. Jurusan Pendidikan Sendratasik. Fakultas Bahasa dan Seni. Universitas Negeri Semarang.

Cahyono, A, Bintang H. P, dan Muhammad Hasan B. 2016. "Tanda dan Makna Teks Pertunjukan Barongsai". Jurnal Mudra. Vol.31. Nomor 1. Hlm. 22-36. Semarang. Jurusan Pendidikan Sendratasik. Fakultas Bahasa dan Seni. Universitas Negeri Semarang.

Hadi, Sumandiyo. 2007. Sosiologi Tari Sebuah Pengenalan Awal. Yogyakarta: Pustaka.

2006. Seni Dalam Ritual Agama. Yogyakarta: Pustaka.

Indriyanto, R. 2011. "Pengaruh Tari Jawa pada Tari Baladewan Banyumasan". Harmonia. Vol. XI. Nomor 1. H1m. 57-67. Semarang: Universitas Negeri Semarang.

Jaeni. 2014. Kajian Seni Pertunjukan Dalam Perspektif Komunikasi Seni. Bogor. PT Penerbit IPB Press.

Jazuli, M. 2001. Metode Penelitian Kualitatif. Semarang: Universitas Negeri Semarang.

2011. Sosiologi Seni (Pengantar Dan Model Studi Seni). Surakarta: Program Buku Teks Lembaga Pengembangan Pendidikan UNS.

2016. Peta Dunia Seni Tari. Sukoharjo: CV. Farishma Indonesia.

Kaelan. 1998. Filsafat Bahasa: Masalah Dan Perkembangannya. Yogyakarta: Paradigma.

Koentjaraningrat. 2002. Manusia dan Kebudayaan di Indonesia. Jakarta: Djambatan Anggota IKAPI.
2015. Pengantar Ilmu Antropolgi. Jakarta: PT Rineka Cipta.

Kusmayati, A.M. Hermien. 2000. ArakarakanSeni Pertunjukan Dalam Upacara Tradisional di Madura. Yogyakarta: Tarawang Press.

Mahmud, M. Dimyati. 1990. Psikologi: Suatu Pengantar. Yogyakarta: BPFE.

Maryono. 2011. Penelitian Kualitatif Seni Pertunjukan. Surakarta: ISI Press Solo.

Moleong, Lexy J. 2010. Metodologi Penelitian Kualitatif. Bandung: PT Remaja Rosdakarya.

Mulyana, Dedi. 2010. Komunikasi Lintas Budaya. Bandung: PT Remaja Rosdakarya.

Poerwanto, Hari. 2000. Kebudayaan dan Lingkungan Dalam Perspektif Antropologi. Yogyakarta: Pustaka Pelajar.

Ritzer, George. 2011. Sosiologi Ilmu Pengetahuan Berparadigma Ganda. Edisi ke-1. Terjemahan Alimandan. Jakarta: Rajawali Press.

Rohidi, Tjetjep Rohendi. 2011. Metodologi Penelitian Seni. Semarang: Cipta Prima Nusantara Semarang.

Sedyawati, Edi. 2012. Budaya Indonesia Kajian Arkeologi, Seni, Dan Sejarah. Jakarta: Rajawali Press.

Soedarsono. 2002. Seni Pertunjukan Indonesia di Era Globalisasi. Yogyakarta: Gadjah Mada University Press.

Sugiyono. 2011. Metode Penelitian Pendidikan (Pendekatan Kuantitatif, Kualitatif, Dan $R \& D)$. Bandung: Alfabeta.

Sumaryanto, Totok. 2007. Pendekatan Kuantitatif dan Kualitatif dalam Penelitian Pendidikan Seni. Semarang: Universitas Negeri Semarang Press.

Sumaryono. 2011. Antropologi Tari dalam Perspektif Indonesia. Yogyakarta: Badan Penerbit ISI Yogyakarta.

Triyanto, Nur Rokhmat, Mujiyono dan Eko Sugiarto. 2016. "The Art Expression Of Coastal Javanese Islam Society". Jurnal 
Komunitas. Vol VIII. Nomor 1. Hlm. 94101. Semarang: Universitas Negeri Semarang.

Wiyoso, Joko. 2012. "Motivasi Masuknya Campursari ke dalam Pertunjukan Jaran Kepang". Harmonia.Vol. 12. Nomor 1. Hlm. 44-51. Semarang: Universitas Negeri Semarang.

Verulita, Esti, Agus Cahyono. 2016. "Nilai Budaya dalam Pertunjukan Rapai Geleng Mencerminkan Identitas Budaya Aceh". Catharsis: Journal Of Arts Education. Vol.V. Nomor 1. Hlm. 1-7. Semarang. Jurusan Pendidikan Sendratasik. Fakultas Bahasa dan Seni. Universitas Negeri Semarang. 